\title{
QUALITY PERFORMANCE: THE CASE OF CONSTRUCTION PROJECTS IN THE ELECTRICITY INDUSTRY IN KENYA
}

\author{
N.O. Ogano ${ }^{1}$ and L. Pretorius* \\ Department of Engineering and Technology Management \\ University of Pretoria, South Africa \\ nomondi@kplc.co.ke, leon.pretorius@up.ac.za
}

\begin{abstract}
Pressure from the Government of Kenya to have citizens connected to electricity as a means of improving their standard of living has resulted in a focus on the electricity utilities to expand the power distribution network. Contractors have therefore been approved to expedite the process. This has, however, resulted in sub-standard work being done by some of the contractors. The main objective of the research is to determine the critical factors that are instrumental in the delivery of quality construction projects for the electricity industry of Kenya. The results of the research reveal that there are areas in which the electricity utilities and the associated contractors perform poorly, indicating the need to improve the quality of completed projects.
\end{abstract}

\section{OPSOMMING}

Druk van die regering van Kenia om sy burgers se lewenstandaard te verhoog, het aanleiding gegee tot 'n behoefte aan die vermeerdering van elektriese aansluitings. Dit het verder daartoe aanleiding gegee dat elektrisiteitsverskaffers die elektrisiteitsverspreidingsnetwerk voortdurend moes vergroot. Om die proses te verhaas, is kontrakteurs aangestel om sekere werk te doen. Dit het egter daartoe gelei dat sekere subkontrakteurs substandaard werk lewer. Die hoofdoel van die navorsing is om kritiese faktore te identifiseer wat aflewering van kwaliteit konstruksieprojekte in die elektrisiteitsindustrie van Kenia beïnvloed. Die resultate van die navorsing dui daarop dat daar areas is waar die elektrisiteitsverskaffers self asook die kontrakteurs nie na wense presteer nie. Die behoefte aan kwaliteitsverbetering in die voltooiing van projekte word geïllustreer.

\footnotetext{
${ }^{1}$ The author was enrolled for an MEng degree at the Graduate School of Technology Management, University of Pretoria.

*Corresponding author
} 


\section{INTRODUCTION}

In the modern construction industry, quality management is considered a major function of any organisation; and according to Jaafari [5], one of the most perplexing issues facing companies is their inability to become quality-focused. Quality assurance is typically viewed as no more than an administrative burden, and no dialogue is conducted with users of the product or service. Rework, notes Jaafari [5], has therefore become common in most construction projects. Rework occurs when a product or service does not meet the requirements of the customer. Consequently the product is altered in accordance with customer requirements. With this in mind, rework includes the correction of defects, and may also include variations. According to Satterfield [14], utility systems need infrastructure to last as long as possible, and one way to ensure longevity is through quality control; but having good quality control in construction projects also requires the performance of quality inspections.

Quality is defined as conformance to requirements [3], with the belief that any product that is consistently produced to its design specifications is of high quality. Ultimately it may be noted (according to Crosby [3]) that the goal of quality improvement is zero defects, to be achieved through prevention rather than after-the-fact inspection. Quality remains a critical issue for the construction industry, and Karim et al. [7] point out that the cost of quality can be as high as $12 \%$ of a company's total costs. On the other hand, Giakatis et al. [4] note that quality-related costs represent a considerable proportion of a company's total costs, and quality costs in general can range between $5 \%$ and $30 \%$ of sales. Giakatis et al. [4] define quality cost as the cost of all efforts that seek to ensure that the product meets specified requirements, while Mukhopadhyay [11] defines quality costs as the costs associated with preventing, finding, and correcting defective work.

According to Bland et al. [1], the 'cost of poor quality' to an organisation is the difference between the actual operating cost and what the operating cost would be if there were no failures in its systems and no mistakes by its staff. They define 'prevention cost' as the cost of any action taken to prevent or reduce the future risk of non-conformity - for example, the costs of implementing a quality system and employing a quality manager/department. They further define 'appraisal cost' as the cost of evaluating the achievement of quality, including inspection, testing, and quality audit, while 'failure (internal) cost' is the cost arising within an organisation due to non-conformities or defects, such as scrap, rework, and redesign. They define 'failure (external) cost' as the cost arising after delivery to a customer or user due to non-conformities or defects, such as the cost of claims against warranty, replacement, and lost orders.

Kenya Power \& Lighting Company Limited was incorporated in 1922 as the East African Power \& Lighting Company (EAP\&L) and became the Kenya Power \& Lighting Company Limited in 1983 [16]. The majority shareholder of Kenya Power \& Lighting Company Limited is the Government of Kenya and its institutions, while private shareholders own the remainder of the shares through the Nairobi Stock Exchange. Before a major restructuring of the power sector in 1997, Kenya Power \& Lighting Company Limited managed all the country's power generating stations on behalf of the government [16].

The power sector in Kenya was liberalised in 1997, which saw the separation of the transmission and distribution functions from generation. The Ministry of Energy is presently responsible for overall policy formulation in the energy sector in Kenya, while Kenya Power \& Lighting Company owns all transmission and distribution assets. The company procures bulk electricity from generating companies and retails it to customers. The Kenya Electricity Generating Company manages all power generation facilities in the country, and sells electricity in bulk to Kenya Power \& Lighting Company Limited. The sector also has independent power producers who build, operate, and own power stations, then sell power in bulk to Kenya Power \& Lighting Company with whom they sign power purchase agreements [16]. 
The stakeholders in the electricity construction industry in Kenya include existing customers, Kenya Power \& Lighting Company management, employees of the company, the Electricity Regulatory Commission of Kenya, prospective customers of the company, and the general public. Concerns have been raised by stakeholders about the quality of new projects undertaken by both Kenya Power \& Lighting Company and the contractors; and the poor quality of work that is evident in the final 'as constructed' projects could be a result of incompetence on the part of the contractors, procurement shortcomings, design problems, decreasing competence levels of the company's technical staff, and many other reasons that are offered to explain this anomaly. This research therefore aims to identify and study the critical factors that affect the quality of such projects.

Consumers or employees often judge the quality of a product or service on the basis of a variety of information cues that are associated with the product [8]. These informational cues have been dichotomised into intrinsic and extrinsic cues [8]. Intrinsic cues involve the physical elements of the products - for example, flavour, colour, or texture; while extrinsic cues are product-related but not part of the physical product itself. They are by definition outside the product - for example, price, brand name, and level of advertising [8]. They further note that perception plays a significant role in determining the quality of the constructed work, especially in comparing one completed project with another on aspects such as the form and aesthetics of the work. This research relies heavily on the perception of respondents to the various construction quality dimensions, based on individual observations.

\section{RESEARCH PROBLEM AND METHODOLOGY}

Similar studies have previously been done in the area of quality in construction. Serpell et al. [15] carried out a study specific to the Chilean construction industry, where they concluded that a large number of problems plaguing construction quality in Chile are due to a lack of integration between the different industry representatives, and to poor cooperation and teamwork in the development of construction projects. Jha and lyer [6] conducted a similar study to determine the reasons for underperformance in the quality of Indian construction projects, and concluded that project manager competence, top management support, and interaction between project participants are factors that contribute positively to achieving the desired quality level, while conflict among project participants, ignorance and lack of knowledge, and hostile socio-economic and climatic conditions adversely affect the quality of construction projects in India.

No similar study has been done into addressing specific quality problems in the electricity utility construction industry in Kenya, which is driven by government desire for rapid expansion of the power distribution network to the rural areas while using contractors who are essentially new to this type of work.

The research objectives of the study were as follows:

- To identify and evaluate the various factors that affect the quality of construction projects in the electricity industry in Kenya.

- To suggest ways to improve the quality of construction projects in the electricity industry in Kenya.

Delivering quality in construction requires a stable level of workload while encouraging and assisting construction firms to develop quality standards, including industry-wide programmes to raise quality standards. One of the key issues that affect construction quality is demand instability, which leads to cash flow problems, a drain on skills, widespread use of temporary workers, and supervision problems. It emerged that a more functional contractor evaluation process is necessary if quality is to be realised. The model in Figure 1, on factors affecting quality in the construction industry, was found to be relevant to the electricity construction industry in Kenya, and was used in this paper. 


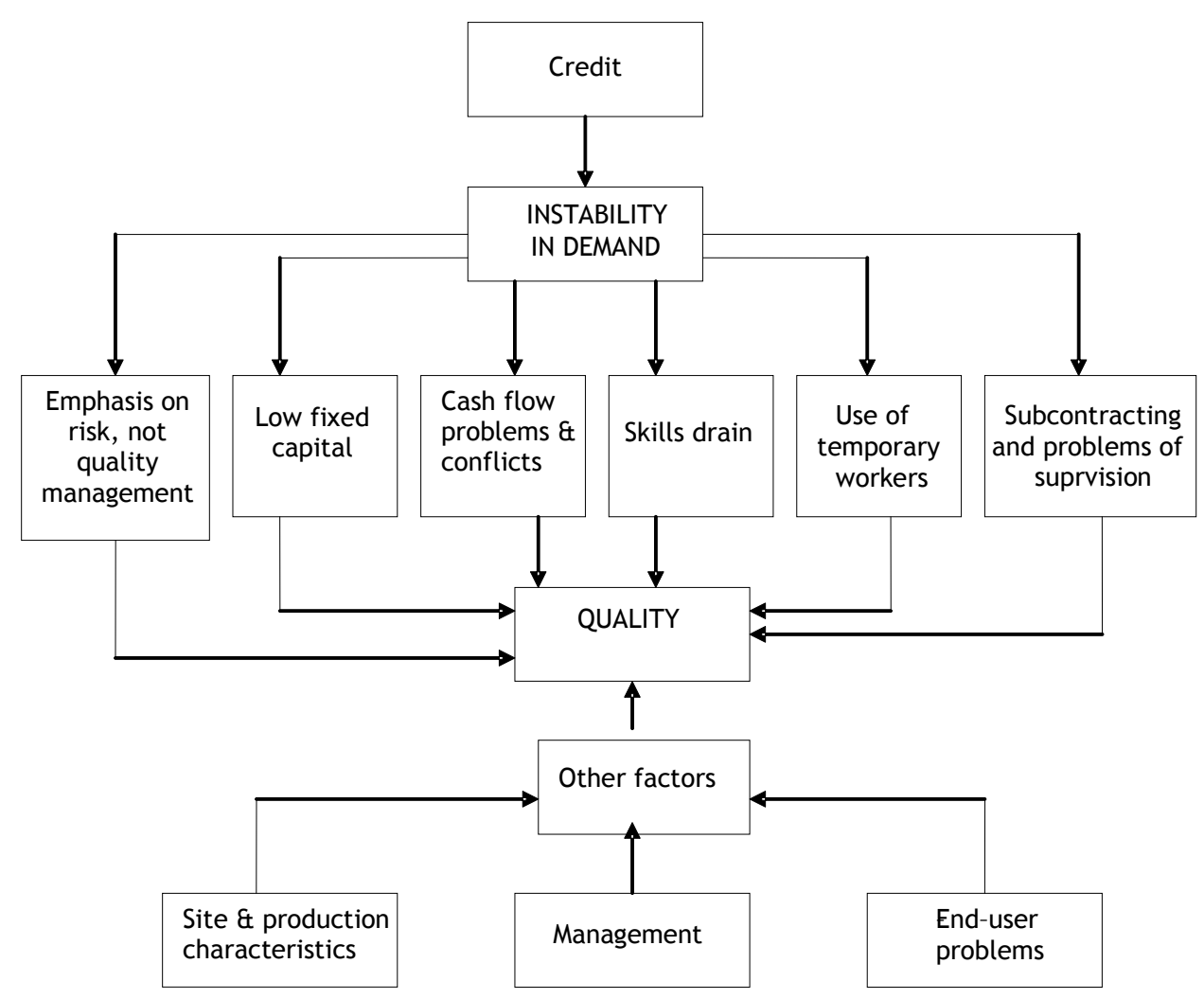

Figure 1: Factors affecting quality in the construction industry [13]

The research method employed is a descriptive study relying on an experience survey of the participants. Descriptive designs result in a description of the data, whether in words, pictures, charts, or tables, and whether the data analysis shows statistical relationships or is merely descriptive [9]. Descriptive research is used to obtain information concerning the current status of the phenomena to describe 'what exists' with respect to variables or conditions in a situation. According to Cooper [2], the objective of a descriptive study is to learn the who, what, when, where, and how of a topic.

In this research, the population of interest comprised contractors and supervisory staff undertaking construction work in the power industry in Kenya, spread geographically throughout the country. The population had 200 pre-qualified contractors and 50 supervisory staff. A sample of 50 was used for this study, which comprised 40 contractors and 10 supervisory staff of the Kenya Power \& Lighting Company, representing $20 \%$ of the sample population of 250. At the time of the study, the Kenya Power \& Lighting Company operated throughout the country, and its operations were divided into four regions: Nairobi, Coast, West Kenya, and Mount Kenya. The company construction teams, as well as prequalified contractors, operated in all four regions, while some of the construction projects were supervised directly from central office.

The apportionment of targeted sample units in each of the four regions of the company and at central office is as indicated in Table 1 and Table 2. 


\begin{tabular}{|l|c|c|c|}
\hline & Population (N) & \multicolumn{2}{|c|}{ Sample units (n) } \\
\hline Region & $\begin{array}{c}\text { Number of } \\
\text { supervisory staff }\end{array}$ & $\begin{array}{c}\text { Percentage (\%) of } \\
\text { sample units }\end{array}$ & $\begin{array}{c}\text { Number of staff in } \\
\text { target sample }\end{array}$ \\
\hline NAIROBI & 10 & 20 & 2 \\
\hline COAST & 8 & 16 & 2 \\
\hline WEST KENYA & 10 & 20 & 2 \\
\hline MT KENYA & 8 & 16 & 3 \\
\hline $\begin{array}{l}\text { CENTRAL } \\
\text { OFFICE }\end{array}$ & 14 & 28 & 10 \\
\hline Gross & 50 & 100 & 2 \\
\hline
\end{tabular}

Table 1: Calculated apportionment of targeted sample units from the population of KPLC employees supervising construction work

\begin{tabular}{|l|c|c|}
\hline Population $(\mathrm{N})$ & \multicolumn{2}{|c|}{ Sample units (n) } \\
\hline Number of contractors & $\begin{array}{c}\text { Percentage (\%) of } \\
\text { sample units }\end{array}$ & $\begin{array}{c}\text { Number of contractors in target } \\
\text { sample }\end{array}$ \\
\hline 200 & 20 & 40 \\
\hline Gross & 100 & 40 \\
\hline
\end{tabular}

Table 2: Calculated apportionment of targeted sample units from the population of contractors

A probability sampling method was used to select the sample units. The primary data was obtained using a structured questionnaire, which was self administered and was sent to respondents through the company's internal mail delivery system and returned the same way for the supervisory staff of the company. Contractors to be sampled were telephoned and asked to obtain the questionnaire, which they individually returned to the company offices after completion. The data was analysed using descriptive statistics, whereby data in Part A of the questionnaire was analysed using frequency tables, while the data of the Likert scale scores in Part B of the questionnaire was analysed using frequency tables, means, and standard deviation.

In the coding, the Likert scale answers were assigned from 'to a very large extent' (1) and 'to no extent at all' (5) for ease of data entry and analysis. Two questionnaires were rejected due to incomplete information in some parts. A total of 44 of the targeted 50 respondents $(88 \%)$ responded and returned the questionnaires. The response rate compares favourably with similar studies, such as the $84 \%$ response rate attained by Mwaura [12], and the $73 \%$ response rate by Maina [10], both studies being on perceived service quality. This response rate was therefore found to be adequate and sufficient for the purpose of current data analysis. 


\section{RESULTS}

The respondents' level of education when college / university levels were aggregated was at $88.1 \%$. It is evident that a majority of the respondents were fairly well-educated, as indicated in Table 3.

\begin{tabular}{|l|c|c|}
\hline & Frequency & Percentage \\
\hline Secondary & 5 & 11.9 \\
\hline College & 19 & 45.2 \\
\hline University & 18 & 42.9 \\
\hline Total & 42 & 100.0 \\
\hline
\end{tabular}

Table 3: Educational level

The respondents' gender was dominated by males at $83.3 \%$, while females were $16.7 \%$, as indicated in Table 4.

\begin{tabular}{|l|c|c|}
\hline & Frequency & Percentage \\
\hline Male & 35 & 83.3 \\
\hline Female & 7 & 16.7 \\
\hline Total & $\mathbf{4 2}$ & 100.0 \\
\hline
\end{tabular}

Table 4: Gender

In answer to the comment, 'Quality inspection results are normally documented by contractors', a substantial number of respondents felt that this was happening only to some extent, with a mean of 3.24. This shows that the majority of respondents felt that quality inspection is not taken seriously by most contractors. Figure 2 gives the results obtained after analysis of the parameter.

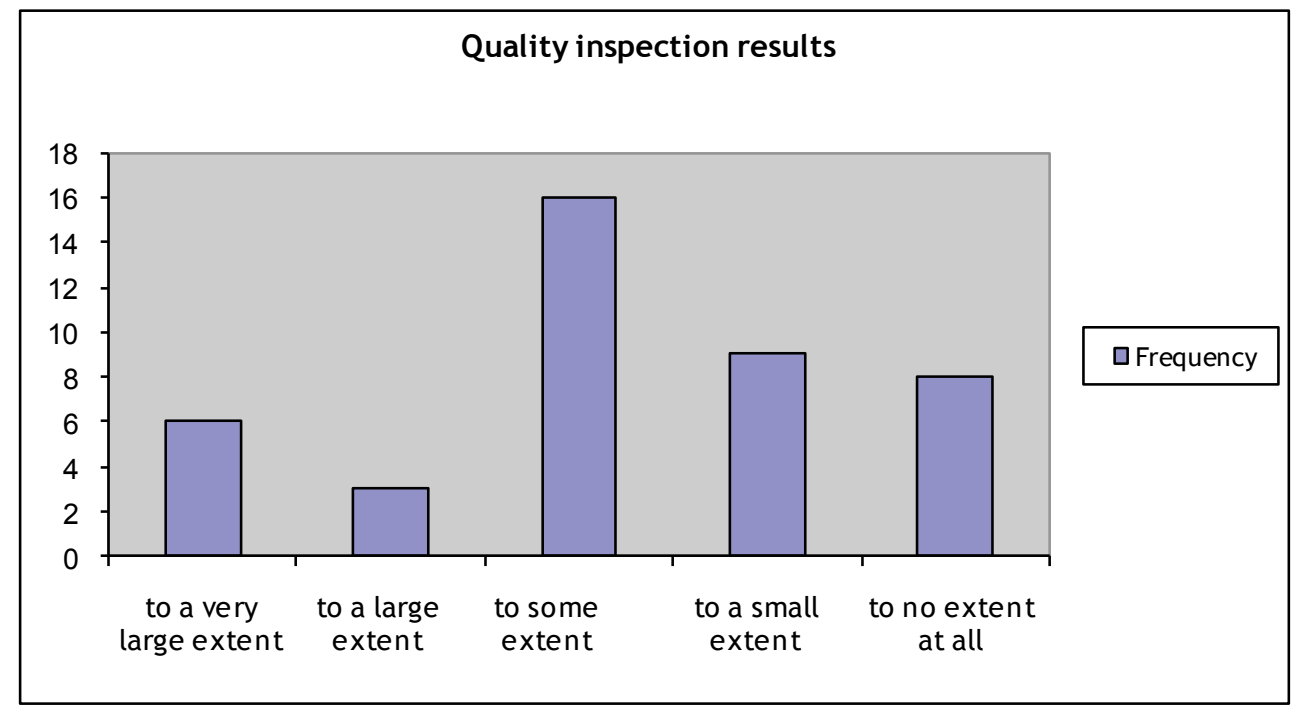

Figure 2: Research question: Quality inspection results are normally documented by the contractor

On the same note, the survey results to the question, 'Is construction work adequate to enable contractors to retain craft personnel?' had a mean of 3.24. This high mean value implies that a majority of respondents felt that available construction work is not adequate 
for most of the contractors, and would therefore suggest that most contractors hire staff on a temporary basis. Figure 3 gives the results of analysis on this dimension.

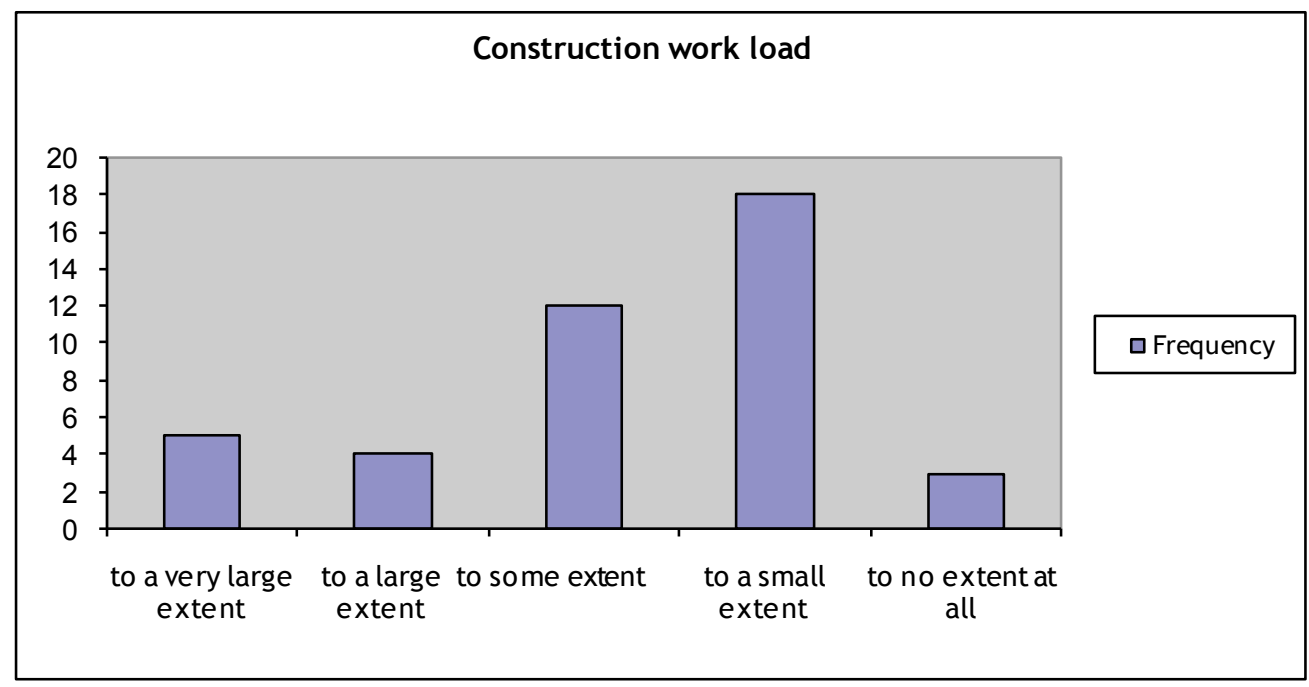

Figure 3: Research question: Construction workload adequate to enable contractors to retain craft personnel permanently

Figure 4 provides the results obtained in answer to the comment, 'Design estimates are normally accurate', and the mean score of 2.74 is an indication that most respondents felt that design estimates are not always accurate.

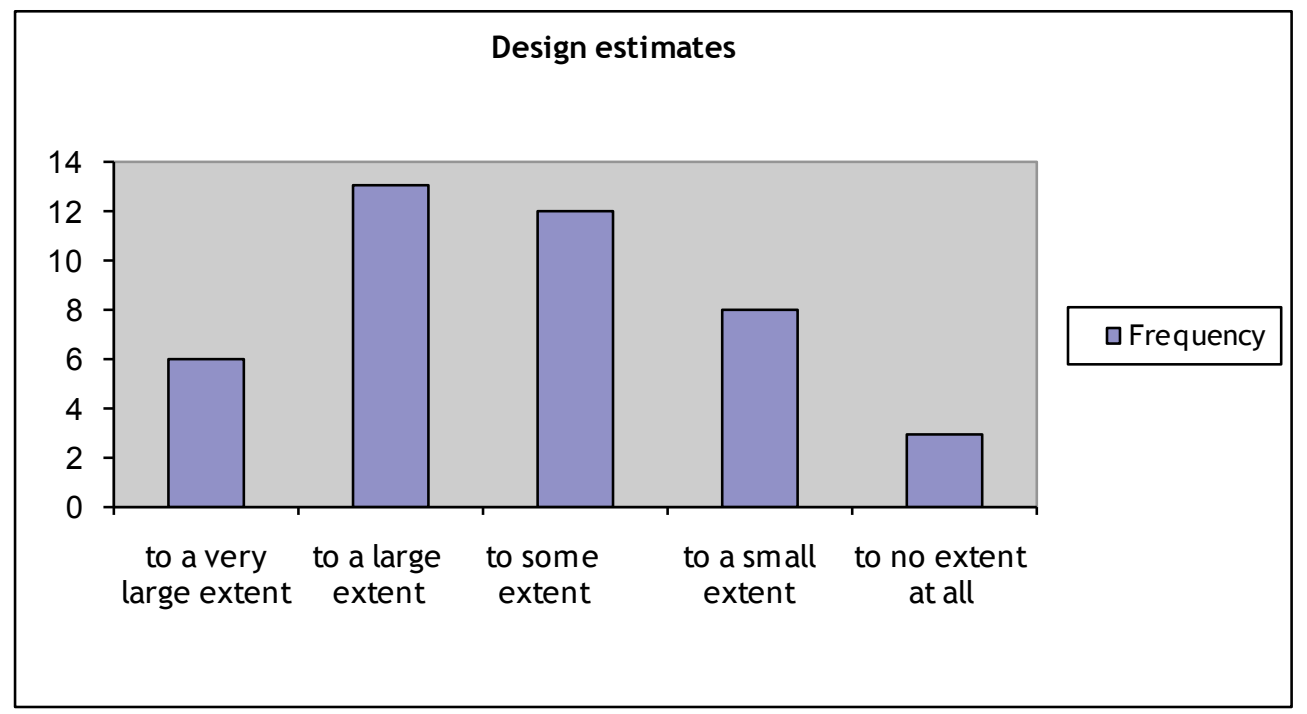

Figure 4: Research question: Design estimates are normally accurate

Figure 5 summarises the results from the respondents' answers to the comment, 'Construction non-conformities are normally analysed to find cause' which had a mean score of 3.05. This implies that, according to the respondents, this is normally only done to some extent, and therefore would mean that there is a chance that non-conformities from one project could be repeated in another project due to the lack of learning. 


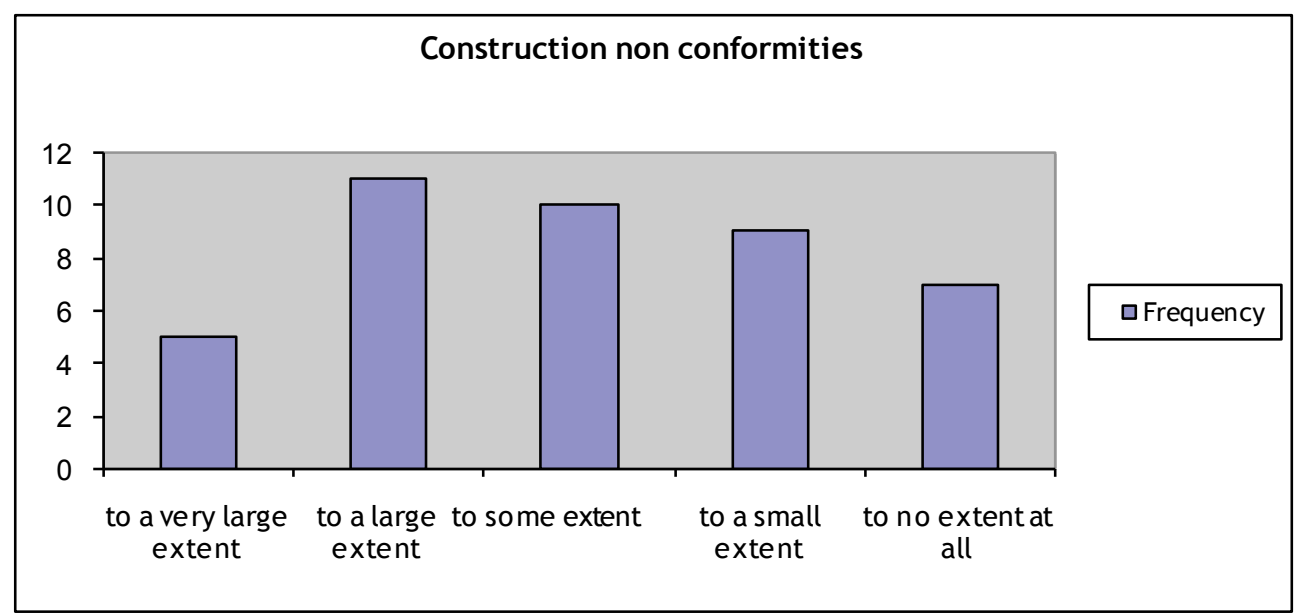

Figure 5: Research question: Construction non-conformities normally analysed to find cause

Analysis results depicted in Figure 6 are the result obtained in answer to the question, 'Does KPLC value quality work?', which had a mean score of 1.86. The majority of respondents felt that this was true to a large extent, and therefore KPLC as a company does value quality work.

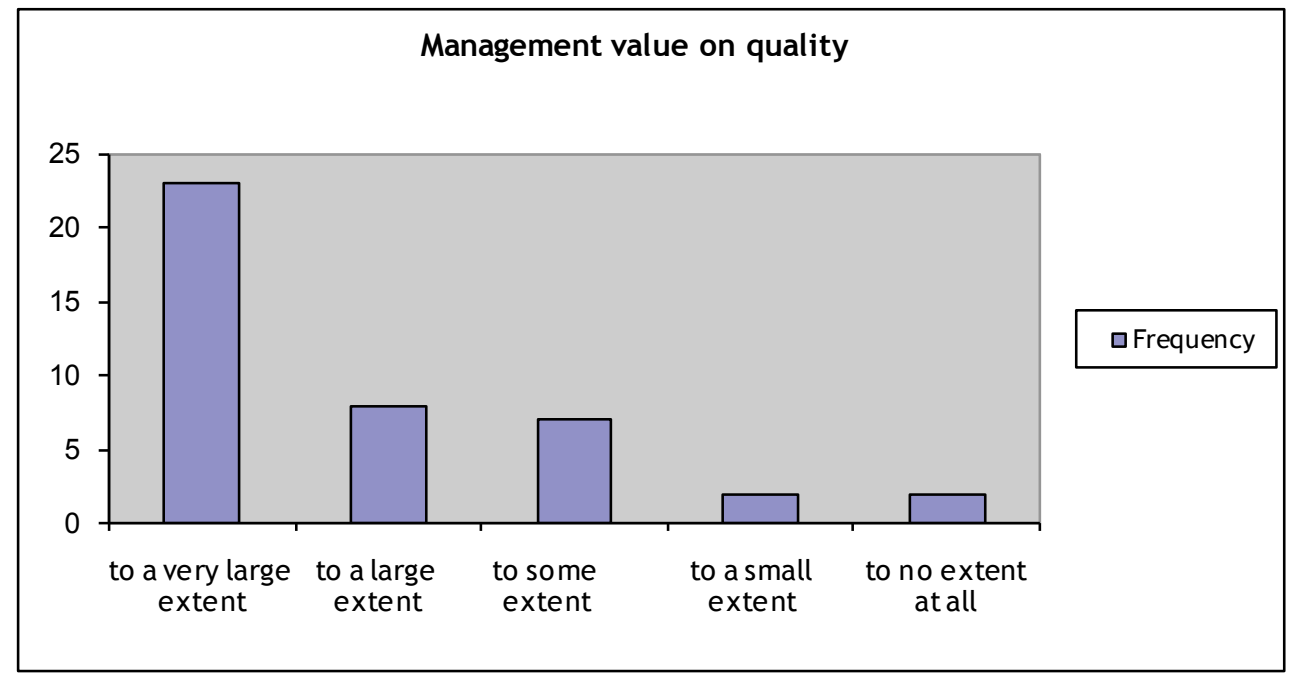

Figure 6: Research question: KPLC management values quality work

Figure 7 provides the result in answer to the comment, 'KPLC has a quality system to ensure quality work', which with a mean score of 1.93 implies that the majority of respondents agreed with this comment to a large extent.

Figure 8 gives analysis results obtained from the respondents in answer to the comment, 'KPLC supervisors are competent for construction supervisory work', which had a mean score of 1.83, and implies that the majority of respondents agreed with this statement to a large extent. 


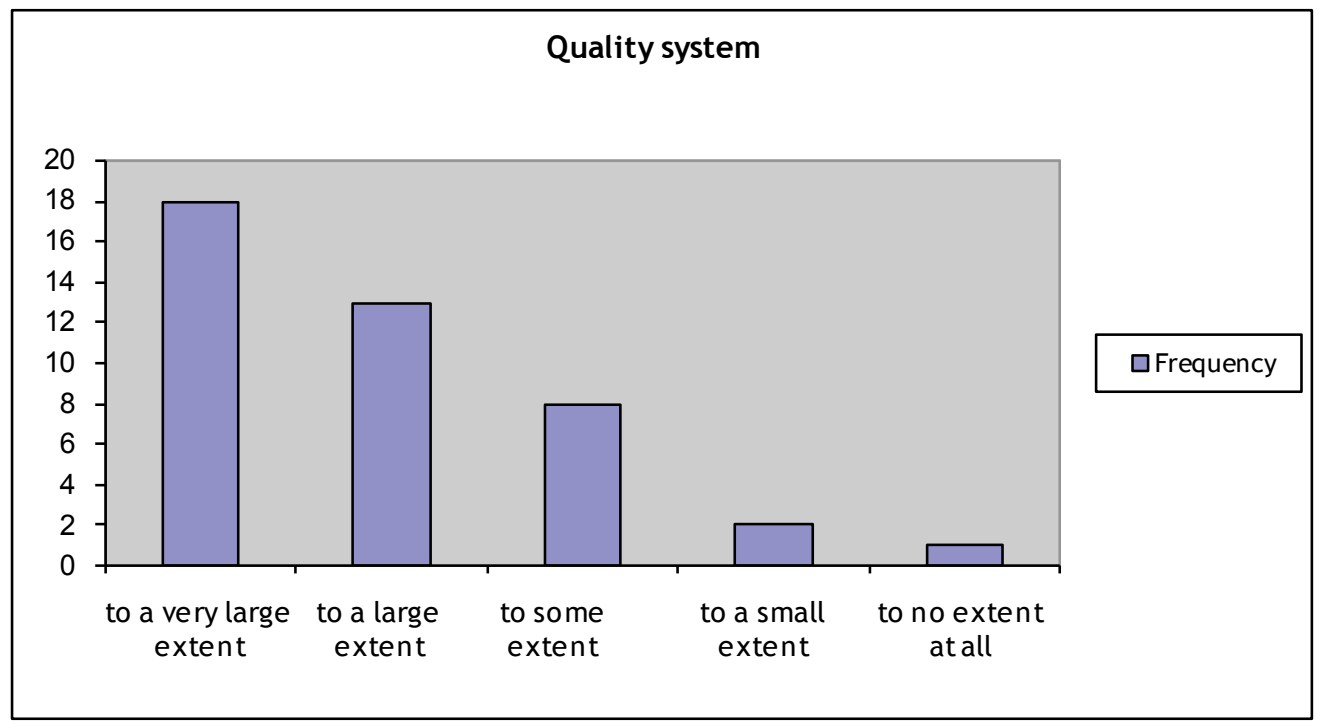

Figure 7: Research question: KPLC has a quality system to ensure quality work

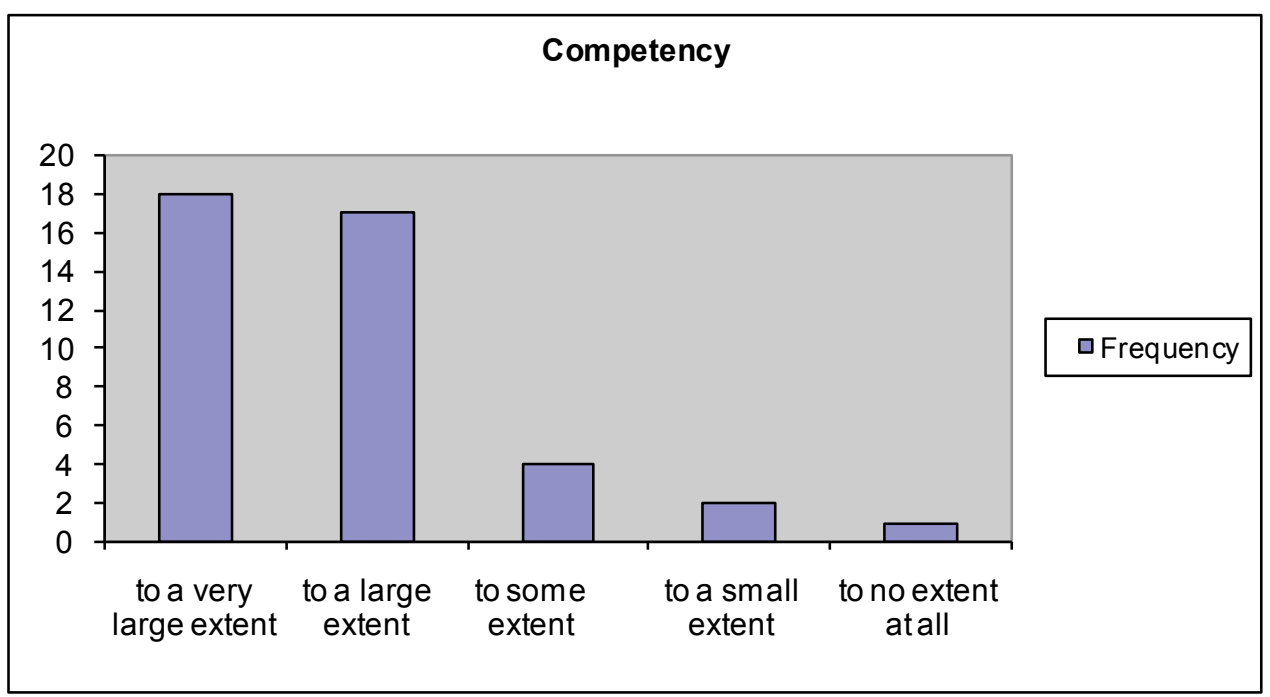

Figure 8: Research question: KPLC supervisors are competent for construction supervisory work

Figure 9 indicates analysis results obtained from the respondents in answer to the comment, 'KPLC supplies good quality materials to contractors', which had a mean score of 1.57 , and implies that the majority of respondents agreed with this statement to a large extent.

\section{CONCLUSION AND RECOMMENDATIONS}

From the results it may be concluded that construction quality inspection results are not usually documented by either the contractors or the utility company's supervisory staff. This means that it is quite possible for the same contractor to repeat the same mistakes, resulting in poor quality work in subsequent projects, and the absence of a paper trail makes it difficult to reprimand the offending contractors. 


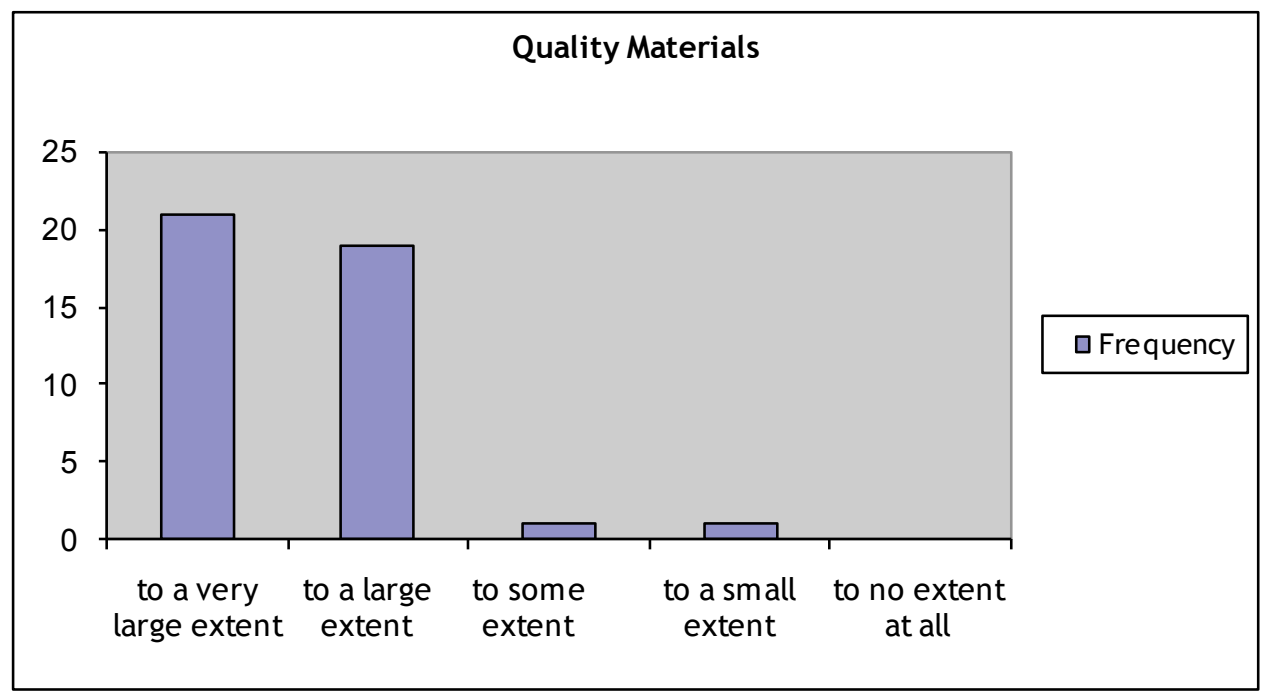

Figure 9: Research question: KPLC supplies good quality materials to contractors

It also transpires that design estimates were not always accurate, and this meant that contractors had to make alterations at the time of construction. This practice is not ideal, and can lead to poor quality work. The results also point to the fact that the construction workload is not adequate for most contractors to retain their skilled personnel on a permanent basis, which means many contractors may end up using temporary staff of questionable competence.

The analysis of key construction quality dimensions also revealed that contractor selection, documented quality systems, and control of non-conformance are areas in which the utilities are managing only to some extent, meaning that the utilities face significant challenges in these key areas, and as a result, construction quality continues to suffer.

The results further indicate that the management of Kenya Power \& Lighting Company values quality work, while the company has a quality management system in place, which is a boost to the efforts to attain high quality in the industry. The results also show that the company, being the leading utility in this industry in the country, supplies good quality materials to the contractors, and that the utility supervisory staff is competent for supervising construction work. Further, the analysis of the key construction quality dimensions also revealed that construction contract administration, quality of specifications, inspection and testing, communication, and culture of excellence, are areas in which the utilities were already doing well to a large extent.

This study helped to identify key factors that are critical to achieving quality in the construction industry, and specifically in the electrical utility environment in Kenya. Furthermore, key areas in which both the utilities and the contractors have achieved remarkable progress have been identified. Areas of weakness that need to be addressed to attain the overall aim of quality in construction projects in this industry have also been highlighted. This therefore makes the issues for achieving quality construction work in this industry in Kenya clearer, so that they can be addressed between the utilities and the contractors.

From the findings, it is recommended that both the electricity utilities and the construction contractors institute and enforce a documented quality management system that will involve documenting quality inspection results, so that learning can take place to ensure that repeat mistakes are avoided. It is also recommended that a system of analysing the 
construction non-conformities be considered by the utilities so that a culture of quality performance may be encouraged amongst the contractors, who number more than 200 . This should make it easier to conduct future contractor pre-qualification exercises, as performance records would be available to assist in the evaluation of past work history. It is further recommended that the utilities short-list only competent contractors, so that those who are pre-qualified can have adequate work that will enable them to retain their skilled personnel, who are key assets in this type of work.

The utilities also need to ensure that all materials are provided to the contractors in time, to avoid situations where contractors are given only part of the materials they require for each project. This should enable the contractors to save on the cost of transporting the materials. The utilities also need to ensure that contractors are paid promptly after completion of the projects, to help them attain financial stability and assist in skills development. The designs done by the planning departments of the electricity utilities also need to ensure that the design drawings are accurate to avoid alterations at the time of construction work. Further, proper and strict pre-qualification of contractors should ensure that those who are incompetent are eliminated beforehand.

The issue of lack of adequately-trained staff also needs to be addressed. This can be done through a joint exercise whereby the utility offers the training to the contractors, while the government and the utilities should explore ways through appropriate policy frameworks to institute and enforce funding for the training of the construction crew, as part of the exercise in capacity-building for this vital resource in the country.

Having concentrated on the construction quality issues in the electricity industry in Kenya in this study, future research could be done to investigate the key success factors in the construction industry in Kenya, as well as the relationship between training contractors and performance in this industry, so as to judge whether the training offered to the contractors makes a difference.

\section{REFERENCES}

[1] Bland, F.M., Maynard, J. \& Herbery, D.W. 1998. Quality costing of an administrative process, The TQM Magazine 10(5), pp. 367-377.

[2] Cooper, D.R. \& Schindler, P.S. 2001. Business research methods, $7^{\text {th }}$ edition, Irwin/McGraw-Hill, Singapore.

[3] David, G.A. \& Artemis, M. 1986. A note on quality: The views of Deming, Juran and Crosby, Harvard Business school cases, Sept. 1986.

[4] Giakatis, G., Enkawa, T. \& Washitani, K. 2001. Hidden quality costs and the distinction between quality cost and quality loss, Total Quality Management 12(2), pp. $179-190$

[5] Jafaari, A. 1996. Human factors in the Australian construction industry: Towards total quality management, Australian Journal of Management, 21(2), pp. 159-85.

[6] Jha, K. \& lyer, K. 2006. Critical factors affecting quality performance in construction projects, Total Quality Management, 17(9), pp.1155-1170.

[7] Karim, K., Marosszeky, M. \& Davis, S. 2006. Managing subcontractor supply chain for quality in construction, Engineering, Construction and Architectural Management, 13(1), pp.27-42.

[8] Kaynak, E. \& Kara. A. 2002. Consumer perceptions of foreign products: An analysis of product-country images and ethnocentrism, European Journal of Marketing. 36(7/8), pp.928-49.

[9] Key, J.P. 1997. Research design in occupational education. Oklahoma State University.

[10] Maina P.M. 2001. Perceived service quality: the case of Mobile Services. Unpublished MBA Project, University of Nairobi.

[11] Mukhopadhyay, A.R. 2004. Estimation of cost of quality in an Indian textile industry for reducing cost of non-conformance. Total Quality Management, 15(2), pp. 229234. 
[12] Mwaura A.K. 2002. Perceived service quality: The case of the taxi industry in Kenya. Unpublished MBA Project, University of Nairobi.

[13] Pheng, S.L. \& Tan, W. 1996. Public policies for managing construction quality: The grand strategy of Singapore, Construction Management and Economics, 14, pp. 295309.

[14] Satterfield, P.E. 2005. Quality control in construction projects, NESC Engineering Scientist, 5(2).

[15] Serpell, A., Solminihac, H. \& Figari, C. 2002. Quality in construction: The situation of the Chilean construction industry, Total Quality Management, 13(5), pp. 579- 587.

[16] www.kplc.co.ke, 2008. 